\title{
El Derecho administrativo sancionador y su relación con el Derecho penal*
}

\author{
Eduardo Cordero Quinzacara**
}

\begin{abstract}
RESUMEN
Este trabajo tiene por objeto analizar el problema de la relación entre el Derecho administrativo sancionador y el Derecho penal, a partir de los conceptos de delito penal y de infracciones administrativa. El autor plantea que nuestra doctrina y jurisprudencia ha seguido las teorías y posiciones comparadas, sin reparar respecto de los alcances que tendrían a la luz de nuestra Constitución. A su vez, afirma que la identidad ontológica entre penas y sanciones administrativas es admisible constitucionalmente en el marco de un política represiva que el Estado debe desarrollar a partir del legislador, sujeta a limites sustantivos reconocidos y desarrollados por nuestra jurisprudencia constitucional.
\end{abstract}

Sanción administrativa - derecho penal - derecho administrativo

\section{Punitive administrative law and its relationship with criminal law}

\begin{abstract}
This paper aims to examine, from the doctirne of crime and administrative offenses, the relationship between punitive administrative law and criminal law penalties. The author argues that Chilean doctrine and jurisprudence have followed the foreign law, without due attention to the scope that they should have under the Chilean Constitution. The ontological identity between penalties and administrative sanctions is constitutionally permitted under a repressive policy that the State must develop, subject to substantive limitations recognized and developed by our constitutional jurisprudence.
\end{abstract}

Administrative sanctions - criminal law - administrative law

* Este trabajo es parte de una investigación financiada por FONDECYT referida al proyecto "Fundamentos y principios de la potestad sancionadora de la Administración del Estado en el Derecho chileno" No 1110791.

** Abogado, Doctor en Derecho, Profesor de Derecho administrativo de la Pontificia Universidad Católica de Valparaíso, Chile. Correo electrónico: eduardo.cordero@ucv.cl.

Artículo recibido el 11 de marzo de 2012 y aceptado para su publicación por el Comité Editorial el 26 de octubre de 2012. 


\section{CONSIDERACIONES PREvias}

L as infracciones y sanciones administrativas han planteado desde el punto de vista dogmático una serie de problemas, cuya discusión se ha extendido por más de un siglo sin haber llegado todavía a una respuesta satisfactoria que permita explicar su naturaleza jurídica, los fundamentos constitucionales que permiten sostener la existencia de este poder punitivo en manos de la Administración y el alcance y contenido de los principios a los cuales se encontraría sometida en sus aspectos sustantivos y procedimentales. Por eso no es de extrañar que algunos autores sostengan que la distinción entre la pena penal, la administrativa y la disciplinaria ha llegado a constituir un problema cuyas consecuencias prácticas son graves y cuya solución teórica, entre tanto, dista de ser unánime y satisfactoria ${ }^{1}$, no advirtiéndose con claridad una línea divisoria que separe a estas dos potestades ${ }^{2}$.

Por tal razón, este trabajo tiene por objeto establecer desde una perspectiva dogmática cuál sería la naturaleza, sentido y fundamentos de las sanciones administrativas en el Derecho chileno, teniendo presente que la potestad punitiva del Estado encuentra en el Derecho penal su máxima expresión, sometiéndose su aplicación a una serie de garantías, muchas de las cuales se encuentran atenuadas o derechamente no existen en el ámbito de la Administración del Estado.

Ahora bien, considerando la envergadura de un estudio de esta naturaleza, resulta necesario advertir desde ya cuáles serán los límites que tendrá este análisis:

a) En primer término, se trata de una materia que ha congregado a los estudiosos del Derecho penal y del Derecho administrativo con grados diversos de intensidad en su análisis y con perspectivas claramente diversas, más aún si se tiene presente que se trata de disciplinas que se construyen a partir de conceptos y categorías dogmáticas que no son homogéneas ni intercambiables. Por tal razón, el estudio de la sanciones administrativas exige un esfuerzo que permita conectar y coordinar necesariamente ambas disciplinas, de manera que la respuesta que reciba en el orden penal guarde necesaria correspondencia con el orden jurídico-administrativo.

b) Los materiales, escritos y estudios sobre esta materia son, francamente, abrumadores. Frente a una extensa literatura extranjera, particularmente alemana, italiana y española, nos encontramos en el último tiempo con una cantidad no menor de estudios por parte de la doctrina nacional y, además, una cantidad importante de jurisprudencia constitucional, judicial y administrativa. En este panorama, trataremos de centrar nuestro análisis fundamentalmente en el objeto de este trabajo, dejando para un estudio posterior los demás aspectos que están involucrados. Esto nos permitirá limitar la cita de autores y remitir al lector a las notas al pie, con el objeto de profundizar en algunos de los puntos que no serán desarrollados en esta investigación.

${ }^{1}$ Véase Cury, E. Derecho Penal. Parte General, $8^{a}$ ed., Universidad Católica de Chile, Santiago, 2005, pp. 100 y ss.

${ }^{2}$ Véase, Rodriguez, L. "Bases para distinguir entre infracciones criminales y administrativas", Revista de Derecho, Pontificia Universidad Católica de Valparaíso, Vol. XI, 1987, p. 117. 
c) Existe en nuestra doctrina y jurisprudencia una evidente influencia del Derecho comparado, particularmente español. Así da cuenta, por lo demás, la jurisprudencia constitucional y administrativa. Esto obliga a hacer una exposición más o menos general sobre el estado de la cuestión en dicho país, teniendo presente que la discusión sobre esta materia no es un tema cerrado y que su análisis está sujeto a un régimen jurídico que presenta diferencias sustanciales con el nuestro.

Para el desarrollo de este estudio, comenzaremos por dar cuenta de la existencia de estas sanciones como una realidad histórica (II), para hacer luego un análisis de las diversas tesis o posiciones dogmáticas que se han formulado sobre la materia (III), dar cuenta de la línea seguida por nuestra doctrina y jurisprudencia (IV), y los planteamientos sobre la autonomía del Derecho administrativo sancionador respecto del Derecho penal (IV), para terminar con nuestro planteamiento respecto de cómo se estructura la política represiva en nuestro Derecho y las bases que permiten ubicar a las sanciones administrativas dentro de nuestro ordenamiento constitucional (V).

\section{LAS SANCIONES ADMINISTRATIVAS COMO UNA REALIDAD HISTÓRICA}

Constituye un hecho fuera de discusión que la potestad punitiva en manos de la Administración ha resistido los cambios políticos y diversos momentos históricos, manteniéndose con una intensidad creciente hasta nuestros días, razón por la cual no resulta posible vislumbrar su desaparición, tal como se pretendió hacer bajo los clásicos principios de la revolución liberal que buscaban un Derecho penal legalizado y judicializado: nullum crimen, nulla poena sin lege; nulla poena sine legale iudicium.

Hay diversos factores que han determinado la persistencia y crecimiento de un poder punitivo en manos de la Administración, en donde la doctrina y la literatura especializada han dado cuenta con detalle de fenómeno. No es solo una cuestión de carácter histórico que permite explicar su existencia, ya que también existe una determinación expresa del legislador en orden a seguir por dicho camino, con el objeto de asegurar una intervención oportuna y eficaz de los órganos del Estado mediante la Administración frente a los riesgos y peligros que conlleva una sociedad más compleja y con una capacidad de obrar y, en su caso, de generar una situación de peligro inimaginable en la historia de la civilización. Por lo tanto, no es solo que hayan quedado desperdigadas algunas normas heredadas del antiguo régimen que entregan a la Administración estos poderes punitivos. Corresponde a una necesidad creciente, frente a un aparato judicial cuya capacidad se encuentra superada para asegurar una actuación oportuna de los poderes públicos frente a las conductas que se desencadenan al interior de la sociedad.

No obstante ser un hecho que no se puede desconocer, el estudio de este fenómeno ha dado lugar a una larga discusión acerca de la naturaleza de estos ilícitos, especialmente cuando se enfrentan con los delitos penales. Si bien es cierto existirían algunos elementos externos que permiten hacer una separación: a) el órgano que la aplica, en este caso la Administración del Estado; b) la minus valoración ético-social que se atribuye a estas conductas; c) la gravedad de la sanción, etc. En muchas ocasiones resulta prácticamente imposible hacer la distinción, por tal razón analizaremos el tema dando cuenta de las teorías que se han formulado sobre esta materia. 


\section{LA PROPUESTA Y EL ANÁLISIS DOGMÁTICO EN SU ESTUDIO}

La doctrina ha enfrentado el tema de la naturaleza de las infracciones o contravenciones administrativas, especialmente con el objeto de poder hacer el deslinde de los delitos y las penas. Debido a que se trata de un tema generalmente conocido, nos abocaremos a exponer en sus rasgos generales las tesis que han tratado de dar una respuesta a este problema: la tesis sustancialista centrada en el derecho penal de policía, cuyo principal exponente es Feuerbach; la tesis sustancialista del derecho penal administrativo, representada por Goldschmidt; y la tesis formalista o de la identidad ontológica de estos ilícitos, en donde destaca Merkl.

\section{El iusnaturalismo y el derecho penal de policía}

El problema de la naturaleza de las sanciones administrativas y los elementos que permiten distinguirlas de las sanciones penales fue una cuestión que atrajo la atención de los juristas aun antes de los procesos revolucionarios. Esto ocurrió bajo el influjo de la ilustración y del iusnaturalismo en lo que se denominó el "Derecho penal de policía", que se desarrolla a partir del acotamiento del concepto de policía, cuyo desarrollo y evolución decantó en las diversas técnicas de intervención que tienen por objeto la prevención y la seguridad frente a los peligros (cura advertendi mala futura o Abwebr von Gefabren) ${ }^{3}$. No se debe olvidar que bajo el Estado absoluto los asuntos de policía constituían un ámbito separado del orden jurídico, donde la Administración llegó a gozar de un enorme espacio de libertad, pues las determinaciones que se adoptaran en esta materia eran inapelables. Así las cosas, el análisis de la cuestión no dejaba de ser irrelevante supuesta la delimitación entre asuntos jurídicos, sometidos a control judicial, y asuntos administrativos, propios de la policía ${ }^{4}$. Por lo demás, si bien bajo las monarquías limitadas germánicas este ámbito fue cada vez más estrecho y regulado, siempre daba lugar a un generoso espacio para la discrecionalidad de la Administración.

En este período, la teoría del derecho natural distinguió la figura del delito natural, como ataque a los derechos subjetivos (lesiones o puestas en peligro concreto) de titulares individuales, respecto de las infracciones que constituían únicamente un injusto policial, creado solo por el Estado y, por tanto, no un injusto "natural" o "genuino"5. Uno de los principales exponentes de la teoría del derecho penal de policía será Paul Johann Anselm Ritter von Feuerbach, quien insistirá en esta idea, sosteniendo que las

${ }^{3}$ Véase una síntesis del concepto de policía en Santamaría Pastor, J. A. Principios de Derecho Administrativo, II, 2 ed., Iustel, Madrid, 2009, pp. 258-259.

${ }^{4}$ Sobre esta materia, se puede ver el esclarecedor trabajo de Soto Kloss, E. "La Fiskustheorie, una vinculación privatista del príncipe”, en Derecho Administrativo. Bases Fundamentales, T. I, Editorial Jurídica de Chile, Santiago, 1996, pp. 175-220. Esto se verá especialmente en la aplicación del principio de legalidad y, por tanto, el de reserva legal. A este respecto, véase Santamaría Pastor, J. A. Fundamentos de Derecho Administrativo, Centro de Estudios Ramón Areces, Madrid, 1991, pp. 700-702.

${ }^{5}$ Mattes, H. Problemas de Derecho Penal Administrativo, Revista de Derecho Privado, Madrid, 1979, pp. 144-145. 
infracciones de policía, en la mayoría de las veces, comprenden acciones que son moral y jurídicamente indiferentes, pues constituyen en sus prescripciones inventos de la "policía reinante pro tempore", en cambio los preceptos del genuino derecho penal criminal rigen en todo lugar y todo tiempo ${ }^{6}$. Sin embargo, casi al final de su vida se replantea la idea de la existencia de un derecho penal de policía independiente, llegando a sostener que las infracciones de policía podrían significar la aplicación de auténticas penas. Más aún, el problema lo examina a partir de la Constitución y de las garantías que tienen las personas (libertad, propiedad) sujetas a protección judicial. Así dirá: "Qué es lo que puede quedar en cuanto libertad civil y garantía de los derechos en un Estado, donde no son los tribunales, sino funcionarios de policía los que pueden condenar a los ciudadanos a penas de multa de hasta quinientos florines, a la pérdida de su industria ... a prisión ... la respuesta se encuentra en la pregunta" 7 . Este ha sido, al parecer, uno de los factores que determinó que los intentos posteriores para delimitar el injusto criminal del injusto de policía no diera lugar a resultados que se pudieran destacar, a pesar de los esfuerzos posteriores de autores de influencia hegeliana, como Christian Köstlin que centró la distinción en el objeto: los delitos tiene un objeto que es "en y por sí injusto", mientras que las infracciones de policía tienen por objeto "lo peligroso".

A fines del siglo XIX la doctrina alemana mantuvo las categorías de la teoría del derecho penal de policía, cuya distinción con los delitos se hace en base a dos binomios: lesión del derecho/puesta en peligro del derecho; injusto real/injusto posible ${ }^{8}$. No obstante, en definitiva la doctrina terminó negando la existencia de un derecho penal de policía distinto del criminal. Así, Binding denominó a la legislación de policía como "auténtica legislación penal"9, centrado en la idea que el derecho penal castiga determinadas acciones por atacar un bien jurídicamente protegido, de lo cual no escapa el derecho penal de policía.

La superación del derecho penal de policía se va a producir con su asimilación por el derecho penal propiamente tal, al establecerse un proceso judicial común para todas las acciones punibles. A pesar de los inconvenientes y críticas que se formularon, el

${ }^{6}$ Esto aparece tomado de su obra Ueber di Polizeistraf-Gesetzgebung überhaupt und den zweiten Theil eines "Entwurfs des Strafgesetzbuchs, München 1822", en Feuerbach, p. J. A. Anselm Ritter von Feuerbach's Leben und Wirken: aus seinen ungedruckten Briefen und Tagëbüchern, Vorträgen und Denkschriften, publicado por su hijo Ludwig Feurbach. Leipzig, 1852, pp. 354, 360 y 367. Hemos tenido acceso a una versión facsimilar publicada en Estados Unidos por Nabu Press, 2012. El Proyecto de Código Penal Bávaro que le fuera encargado, dará cuenta de estas ideas, al definir las contravenciones de policía como "acciones u omisiones que en verdad no lesionan en sí y por sí mismo derechos del Estado o de un súbdito, pero que, sin embargo, son mandadas o prohibidas bajo pena a causa del peligro para la seguridad y el orden jurídico”. Véase Mattes, Ídem, pp. 146-147.

${ }^{7}$ Feuerbach, Ídem, p. 347: "Was von der bürgerlichen Freiheit und der Gewähr der Rechte in einem Staat zu halten sei, wo nicht Gerichte, sondern Polizei Beamte die Staatsbürger zu Geldstrafen bis auf 500 Fl.- zum Verlust ihres Gewerbes ... zum Gefängnis (Polizei Arrest)... verurteilen dürfen? hierauf liegt die Antwort schon in der Frage”. Tambén se puede ver Mattes (nota 5), Ídem, p. 149.

${ }^{8}$ Mattes (nota 5), pp. 165 y ss.

9 Ídem, p. 167. 
procedimiento en el caso de las contravenciones se desarrolló siguiendo la misma forma que para los delitos ${ }^{10}$.

\section{Goldschmidt y la teoría del derecho penal administrativo}

La teoría del derecho penal administrativo surge al paso de una mayor intervención del Estado, producto de la revolución industrial, la inmigración importante de la población desde el campo a la ciudad, el surgimiento de la clase asalariada, el crecimiento de las ciudades, etc. Todo esto marca un cambio sustantivo en la conformación de la sociedad, dando lugar a lo que se denominará como Estado social (Sozialstaat) o Estado de bienestar (Welfare State). Frente al Estado liberal que resguarda los derechos individuales o bienes jurídicos frente a los peligros, el aparato público pasa a cumplir una función más amplia destinada a cuidar y asegurar el bienestar de la comunidad.

El concepto de derecho penal administrativo está estrechamente ligado a la figura de James Goldschmidt. En esta tarea este autor encontró en el pensamiento de diversos autores los elementos necesarios para desarrollar, en el marco de la teoría de la Administración y del Derecho administrativo, sus concepciones respecto del poder punitivo de la Administración ${ }^{11}$. Además, su pensamiento ha sido de gran influencia tanto en el Derecho alemán como italiano, siendo de referencia obligada en la literatura española y latinoamericana.

En términos generales, Goldschmidt destaca los deberes que tiene el hombre como miembro de una comunidad, lo cual le impone deberes en la prevención de peligros y en la promoción del bienestar, materias que están a cargo de la Administración. Estos deberes se distinguen de aquellos que le corresponden al particular como individuo, en donde se manifiesta su libertad o poder-querer (orden jurídico) y cuya infracción es sancionada por el derecho penal judicial. Así es posible distinguir entre los deberes en el marco de un orden jurídico, que supone la libertad de la persona, y los deberes que emanan de la Administración, que supone la pertenencia a una comunidad y, por tanto, el deber de asegurar su buen orden. En el primer caso, el fin del derecho es "proteger las esferas humanas de voluntad" y en el segundo la "promoción del bien público y estatal".

Esta separación lo lleva a establecer diferencias entre una y otra infracción, así como las consecuencias jurídicas que derivan de aquellas y explicar la separación que existe entre Justicia y Administración.

${ }^{10}$ Así lo estableció la Ordenanza Procesal Penal del Reich de 1 de febrero de 1877 (Die Strafprozeßordnung vom 1.2.1877 für das Deutsche Reich). Las principales críticas en esta materia fueron formuladas por Reinhard von Frank, a pesar que no cuestionó la decisión de fondo de asimilar las contravenciones a los delitos, haciendo desaparecer el derecho penal de policía. Sus cuestionamientos estaban orientados a un tratamiento procesal diverso, considerando la menor gravedad de las contravenciones. Véase Matte, Ídem, pp. 173-176.

11 En primer término, destaca Sthal, quien puso el acento en el carácter no solo preventivo de la actividad de policía, sino también en su función de cuidado del bien común. También recoge de Lorenz Von Stein la separación de la actividad de la Administración y la administración de justicia. Por último, de Otto Mayer toma un concepto paralelo de orden jurídico que circunscribe el objeto de actuación de la Administración. Ídem, pp. 178-184. 
a) En los delitos el elemento característico es la antijuridicidad, que se traduce en un daño de bienes jurídicos portadores individuales de voluntad (damnun emergens), mientras que la violación de las infracciones administrativas conlleva una antiadministratividad, que se traduce en no alcanzar un objeto o meta impuesto por la Administración, como es el bienestar público (lucrum cesans). En este sentido, la antiadministratividad es la peculiar omisión del apoyo a la Administración del Estado dirigida a la promoción del bien público.

No obstante lo anterior, nuestro autor reconoce que esta separación no es absoluta, sino relativa, pues bien puede ocurrir que una infracción administrativa se convierta en delito, como consecuencia de elevar a la forma de bien jurídico determinados bienes públicos, para mantener el orden jurídico. De esta forma, separa los bienes jurídicos en primarios (portadores individuales de voluntad) y secundarios (como un medio de protección de bienes jurídicos primarios, vgr. moralidad, religión, salubridad, medio ambiente). Este cambio o modulación dependerá, según Goldschmidt, de las concepciones locales y temporales, al punto de señalar que existen pocos delitos jurídicos que no hayan recorrido el estadio de los delitos administrativos. Esta distinción le permite conceptualizar el derecho penal administrativo como "el conjunto de aquellos preceptos por medio de los cuales la Administración del Estado a la que se ha confiado la promoción del bien público o del Estado, enlaza, dentro del marco de la autorización jurídico estatal, en forma de preceptos jurídicos, una pena como consecuencia administrativa a la contravención de un precepto administrativo como tipo" 12 .

b) En segundo lugar se centra en los elementos formales. En este sentido señala que la pena administrativa es propia de la actividad administrativa y es aplicada por la Administración del Estado mediante un acto administrativo. Esto lo aleja de los delitos jurídicos, que son aplicados por la autoridad judicial, siguiendo un procedimiento de la misma naturaleza y que culmina con una sentencia. Esta separación decanta en el régimen jurídico aplicable: el injusto administrativo es un fenómeno del derecho administrativo, además, es consecuencia de la omisión del ciudadano en su deber de apoyo o de ser auxiliar de la Administración.

Por tal razón, Goldschmidt sostiene que al lado del auténtico derecho penal aparece un pseudoderecho penal, cuya naturaleza es y sigue siendo la propia de un instituto del Derecho administrativo.

c) Por último, insistiendo en el punto anterior, nos señala que la pena administrativa constituye un poder penal peculiar, incluso originario de la Administración, cuya aplicación o castigo no corresponde a la autoridad judicial. Sin embargo, en este punto va más lejos y llega a sostener que no debiera ser la Administración misma la que debe aplicar estas sanciones, sino que tribunales administrativos, como un mecanismo de protección y garantía de los ciudadanos. En todo caso, se debe reconocer que esta exigencia sostenida no fue siempre compartida por su seguidores. 
Goldschmidt va a insistir en separar los ámbitos del Derecho penal judicial o de justicia frente al Derecho penal administrativo, dotado de elementos que permiten reconocer su autonomía, postulando que las contravenciones administrativas debían ser sancionadas por la propia Administración. Sin embargo, el legislador positivo no lo acompañó en esta labor.

Esta propuesta dogmática produjo inmediatas reacciones con un número importante de seguidores y detractores, hasta finales de la década del 30 del siglo pasado, cuando la doctrina se inclinó de forma inequívoca en contra de su teoría. Es en este período donde encuentra un fuerte respaldo en la obra de Erik Wolf, quien reconoció el carácter penal de estas infracciones, pero puso el acento en el diverso sentido valorativo que tenían con los delitos jurídicos. Así, nos dirá que se trata de una pena que llama al orden de forma enérgica y vigorosa, sin contener una desaprobación en contra de su autor: "El autor no es socialmente dañoso o peligroso, sino socialmente descuidado". Es este elemento ético en el pensamiento de Wolf que le lleva a sostener que el derecho penal administrativo es derecho penal en sentido formal, pero derecho administrativo en el plano material.

Si bien se ha reconocido que Wolf le dio un fundamento filosófico sólido al pensamiento de Goldschmidt, no tuvo las fuerzas de salvar al derecho penal administrativo.

Fuera de las fronteras de Alemania, la influencia de este pensamiento es recibido especialmente por autores italianos. Tempranamente nos encontramos con Ranelletti, quien distinguía entre leyes penales y leyes de policía, considerando si la sanción tenía por objeto la tutela inmediata del Derecho o su tutela mediata. En este caso, se entiende que la tutela es inmediata cuando supone una ofensa, efectiva o potencial, a un derecho determinado, un bien jurídico de otros o el no cumplimiento de un deber específico (malum quia malum). En cambio, las leyes de policía tienen por objeto evitar posibles ofensas al orden jurídico (malum quia probibitum) ${ }^{13}$. Sin embargo, se debe reconocer que a partir de Guido Zanobini, la mayoría de la doctrina italiana ha abandonado este camino y se inclina por un concepto más formal de sanción administrativa ${ }^{14}$.

\section{Las tesis formalistas}

Las denominadas tesis formalistas se han formulado a partir de una crítica de las tesis sustanciales, principalmente aquella desarrollada por Goldschmidt. Hay que tener presente que esta tesis parte de un antecedente previo e inamovible: la imposibilidad de distinguir desde un punto de vista sustantivo entre delitos y penas, por una parte, e infracciones y sanciones administrativas por otra. Por lo tanto, en esta tesis se parte de una identidad ontológica o sustancial entre ambos tipos de ilícitos.

${ }^{13}$ Ranelletti, O. "La polizia di sicurezza", en Primo trattato completo di diritto amministrativo italiano, Orlando V. E. (dir.), IV, Milano: Società Editrice Libraria, 1904, pp. 207-1265.

${ }^{14}$ Zanobini, G. Le sanzioni amministrative. Bocca, Roma, 1924. También se puede ver Gioia, V. y Scavonetto, L. Le sanzioni amministrativa, Giappichelli, Torino, 2009, 492 p.; Casetta, E. Voz: "Sanzioni amministrative", en Digesto pubblico, XII, Torino, 1997, p. 599. 
Sin lugar a dudas, el máximo exponente de la tesis formalista es Adolf Merkl, quien parte de la base de un hecho empírico: la realidad no da cuenta de una pretendida sustantividad de la infracción. El análisis histórico y comparado pone de relieve que muchas veces una acción criminal es tratada en otro tiempo y lugar como infracción administrativa, por tal razón Merkl afirma que esta circunstancia da cuenta que la configuración de una y otra depende siempre de la libre disposición del legislador y, por tanto, se pierden inútiles esfuerzos tratando de determinar qué figuras delictivas corresponden al Derecho penal criminal y cuáles al Derecho penal administrativo. Así, es una "idea quimérica" suponer que existirían elementos sustanciales que nos permitan distinguir entre ambos tipos de ilícitos: "el Derecho positivo, al repartir la competencia entre los Tribunales y las autoridades administrativas, no haría sino dar satisfacción a una necesidad derivada de la naturaleza del hecho sometido, en cada caso, a la sanción penal" ${ }^{15}$.

Siguiendo las concepciones normativistas, este autor pone el acento en los elementos externos de las infracciones administrativas: a) Es una potestad entregada expresamente por el legislador, quien configura el ilícito, determina la sanción y entrega su conocimiento y determinación a la Administración; b) Está sujeta al régimen jurídico que es propio de la Administración del Estado: el Derecho administrativo; c) En su aplicación, se requiere de un procedimiento administrativo previo al cual se debe sujetar cada una de sus etapas; d) La determinación de la infracción, la responsabilidad y la correlativa sanción se establece mediante un acto administrativo.

La solución planteada por esta tesis parece ser, desde un punto de vista lógico, incuestionable. La idea de que los ilícitos administrativos no dan lugar a una lesión o al peligro concreto de un bien jurídico, como ocurre con los delitos, es sumamente discutible, pues da a entender que estas conductas serían indiferentes desde un punto de vista ético-social. Bien señala Welzel, que el legislador no establece sus mandatos o prohibiciones para ejercitar la obediencia de los ciudadanos, sino para crear un estado de situación valiosa, o impedir la producción de un daño ${ }^{16}$. Además, la tesis sustancialista necesariamente excluyen del ámbito de los ilícitos administrativos el concepto de bien jurídico, colocando como objeto de protección el interés de la Administración, siendo que es muy difícil separar cuando está en juego dicho interés o un bien jurídicamente valioso. Nuestro propio ordenamiento jurídico da cuenta de aquello, pues una determinada conducta, por ej. la presentación de declaraciones erróneas, puede constituir delito si se hace de forma maliciosa o una contravención en sus formas de dolo eventual o culpa, pudiendo el legislador perfectamente canalizar estas últimas conductas por la vía penal o administrativa ${ }^{17}$. En otros ordenamientos la cuestión queda aun más de manifiesto, como ocurre en el Derecho español, en donde una misma conducta es sancionada como delito o contravención administrativa dependiendo de la cuantía ${ }^{18}$. En definitiva, la sanción administrativa es en muchos casos expresión de un juicio de disvalor ético-social de una

${ }^{15}$ Merkl, A. Teoría General del Derecho Administrativo, Comares, Granada, 2004, pp. 347 y ss.

${ }^{16}$ Cfr. Welzel, H., “Der Verbotsirrtum im Nebenstrafrecht”, en Juristenzeitung, 1956, pp. 238-240.

17 Véanse los artículos 169 y 173 de la Ordenanza de Aduanas, y los numerales $3^{\circ}$ y $4^{\circ}$ del artículo 97 del Código Tributario.

${ }^{18}$ El artículo 305 del Código Penal Español exige, para la configuración del delito, que la cuantía de la cuota defraudada, el importe no ingresado de las retenciones o ingresos a cuenta, o de las devoluciones 
determinada conducta, por lo cual mal se puede profesar su indiferencia valorativa y, menos aún, centrar en este elemento la distinción con los delitos.

Sin embargo, a pesar de los acentuados argumentos formulados, esta tesis no deja de plantear reparos de diversa naturaleza. En primer lugar, genera una enorme incomodidad el hecho que el legislador pueda libremente determinar qué conductas serían constitutivas de delitos y cuáles meras contravenciones, incluso pudiendo jugar con ellas generando las más diversas variantes, lo cual violenta no solo el principio de la separación de los poderes del Estado, sino una garantía que es fundamental a todo el sistema, como es la libertad de las personas, que es lo que en definitiva se encuentra bajo una latente amenaza. En segundo término, y como consecuencia de lo anterior, existe una natural desconfianza frente al legislador si se le reconoce el poder de configurar libremente estos ilícitos. No solo es el hecho que las sanciones que pueda aplicar la Administración resulten ser más graves que las que se proyectan en sede penal, sino también respecto de las garantías que le asisten a toda persona en dicho ámbito, las que tradicionalmente se encuentran mucho más atenuadas y, en algunos casos, derechamente no existen. Por último, la realidad nos demuestra que hay elementos no solo formales que permiten hacer la distinción entre delitos e infracciones administrativas, entre los cuales se encuentran la gravedad de la sanción, la posibilidad de aplicarlas sin mayores restricciones a las personas jurídicas, la configuración de injustos administrativos cuya valoración ética-social es menor que las contenidas en los delitos, etc. Bien se podría contraargumentar sosteniendo que esto corresponde a un dato empírico, que da cuenta de la forma como ha actuado el legislador, pero nada impide que en el futuro cambie de parecer en esta materia, alterando estos elementos. Sin embargo, es aquí donde surge el problema central de este estudio, pues la conceptualización de los delitos/penas y las infracciones/sanciones administrativas se ha transformado en una cuestión fundamental al momento de establecer cuáles son los principios y, especialmente, las garantías que están en juego respecto de las personas que se le imputan dichos ilícitos. Por lo tanto, no es solo una cuestión dogmática, ya que en este caso también entran otros principios y normas de naturaleza política, especialmente las tradicionales garantías que por siglos se han ido forjando en el ámbito del Derecho penal.

Por tal razón, algunos autores han seguido insistiendo en la idea de buscar elementos sustanciales para la determinación y deslinde de estos conceptos, como ha ocurrido con Zanobini, quien compartiendo la tesis de Merkl, en una versión menos radical nos señala que no es posible aplicar como sanción la privación de libertad y que la multa, a la sazón la principal sanción administrativa, no puede ser convertible en prisión ${ }^{19}$. En una línea similar lo plantea también Girola ${ }^{20}$ y de forma más reciente Sandulli ${ }^{21}$. A su vez,

o beneficios fiscales indebidamente obtenidos o disfrutados exceda de 120.000 euros. Si estos ilícitos se cometen contra la Hacienda de la Comunidad Europea, el monto baja a 50.000 euros.

19 Zanobini (nota 14), p. 34 y ss.

${ }^{20}$ Girola, C. "Sanzioni penali e sanzioni amministrative", en Rivista di Diritto Pubblico, I, 1929, pp. 429 y ss.

${ }^{21}$ Sandulli, A. M. Manuale di diritto Amministrativo, Giuffré, Milano, 1993, p. 174, quien señala que "la sanción administrativa tiene por objeto velar por los intereses afectados y protegidos, en particular los relativos a los deberes generales o especiales hacia la administración pública”. 
en Alemania se insistió en estas posiciones aun después de la segunda postguerra, como ocurre con Eberhard Schmidt, quien se apoya decididamente en la teoría de Goldschmidt, ejerciendo un influjo decisivo en la nueva configuración del derecho penal económico ${ }^{22}$.

Ahora bien, una variante importante de este pensamiento lo constituye la tesis cuantitativa, según la cual es la gravedad de la sanción la que determina si estamos frente a un delito o a una mera infracción administrativa. Esto supone que corresponde al legislador trazar la frontera entre ambas, valorando la gravedad de la conducta y estableciendo la sanción correlativa. Esta es la posición planteada por importantes autores alemanes, como Roxin ${ }^{23}$ y Jakobs ${ }^{24}$. En el mismo sentido se pronuncia en España José Cerezo $\mathrm{Mir}^{25}$ y en nuestro país por Enrique Cury ${ }^{26}$. Sin embargo, siempre subyace a esta tesis cierta idea sustancialista que apunta a la significación ético-social del injusto, sobre todo cuando no se reconocen los límites que tendrán en esta tarea.

Lo expuesto anteriormente es muestra de lo insatisfactorio que resulta la tesis formalista, pues exige algunas matizaciones de no menor envergadura, para comprender desde el punto de vista jurídico-constitucional cómo se explica la existencia de dos manifestaciones del poder punitivo del Estado, la función y límites que tiene el legislador en la configuración de estos ilícitos y, especialmente, las garantías que tienen las personas frente al ejercicio del ius puniendi estatal.

\section{LA LEGISLACIÓN, LA DOCTRINA Y LA JURISPRUDENCIA EN EL DERECHO CHILENO}

\section{Nuestro Derecho positivo}

El tema de las sanciones administrativas aparece recogido por nuestro Código penal en dos de sus disposiciones en los siguientes términos:

Artículo 20. No se reputan penas, la restricción o privación de libertad de los detenidos o sometidos a prisión preventiva u otras medidas cautelares personales, la separación

22 En palabras de Mattes (nota 5), pp. 231-233, atribuye a la pena el sentido ético de expiación, y dentro de la político criminal el ideal de resocialización del enemigo del derecho, lo que no se presenta en las sanciones administrativas, que responden a meras infracciones de orden. Este autor tiene varios trabajos sobre esta materia, pero su pensamiento se puede apreciar en Schmidt, E. Lebrkommentar zur Strafprozessordnung und zum Gerichsverfassunsgesetz. Teil 1, 2a ed., Vandenhoeck \& Ruprecht, Göttingen, 1964, especialmente en los $\mathrm{N}^{\mathrm{os}} 59,126,391-394$ y 397.

${ }^{23}$ Roxin, C. Derecho penal. Parte general. T. I, Civitas, Madrid, 1997, p. 72.

${ }^{24}$ Jakobs, G. Derecho penal. Parte general. 2 ed. Marcial Ponst, Madrid, pp. 65-66.

${ }^{25}$ Cerezo Mir, J. "Límites entre el Derecho penal y el Derecho administrativo", en Anuario de Derecho penal y Ciencias penales, Tomo XXVIII, Fascículo II, mayo-agosto, 1975, pp. 159-173.

${ }^{26}$ Cury señala que entre ambos ilícitos solo puede hacerse una distinción de magnitudes: "El administrativo no es sino un injusto de significación ético-social reducido, que por tal razón solo debe estar sometido a sanciones leves cuya imposición no requiere garantías tan severas como las que rodean a la pena penal”. Cfr. Cury (nota 1), pp. 106-107. 
de los empleos públicos acordada por las autoridades en uso de sus atribuciones o por el tribunal durante el proceso o para instruirlo, ni las multas y demás correcciones que los superiores impongan a sus subordinados y administrados en uso de su jurisdicción disciplinal o atribuciones gubernativas.

Artículo 501. En las ordenanzas municipales y en los reglamentos generales o particulares que dictare en lo sucesivo la autoridad administrativa no se establecerán mayores penas que las señaladas en este libro, aun cuando hayan de imponerse en virtud de atribuciones gubernativas, a no ser que se determine otra cosa por leyes especiales.

Ambas normas son tomadas del Código Penal español de $1848^{27}$ y dan cuenta de la concepción seguidas por los redactores del Código Penal chileno: a) las sanciones administrativas, ya sean disciplinarias o gubernativas, no se reputan penas y, por tanto, se debe entender que las conductas que castigan no son delitos para efectos de dicho Código; b) Las autoridades administrativas no pueden establecer mayores penas que las previstas en dicho Código, salvo que una ley expresamente así lo establezca.

Por su parte, de ambas normas se desprenden dos reglas formales que ha seguido el legislador para identificar las sanciones administrativas: la naturaleza del órgano que la aplica, en este caso la Administración; y su cuantía o gravedad, pues salvo texto legal expreso, no es posible que estas superen a las previstas en el Código Penal para las faltas.

Sin embargo, resulta evidente que en esta materia nuestro ordenamiento jurídico siguió un criterio estrictamente positivo: es el legislador quien determina la autoridad que aplica la sanción y su cuantía o gravedad, sin que se reconozca ningún límite sustancial a la labor que realiza. En tal sentido, y conforme a las mismas disposiciones, es perfectamente posible que la autoridad administrativa aplique sanciones más graves que las previstas en el Código Penal si así lo determina la ley. En buenas cuentas, queda a la discrecionalidad del legislador determinar cuándo estamos frente a una pena o a una sanción administrativa.

${ }^{27}$ A este respecto, el artículo 22 del Código Penal español de 1848 establecía: "No se reputan penas las restricciones de la libertad de los procesados, la separación ó suspensión de los empleados públicos, acordada por las Autoridades gubernativas en uso de sus atribuciones, ó por los Tribunales durante el proceso, ó para instruirlo, ni las multas y demas correcciones que los superiores impongan á sus subordinados y administrados en uso de su jurisdicción disciplinal ó atribuciones gubernativas”. Por su parte, el artículo 505 dispone: "En las ordenanzas municipales y demas reglamentos generales ó particulares de la Administración que se publicaren en lo sucesivo, no se establecerán mayores penas que las señaladas en este libro, aun cuando hayan de imponerse en virtud de atribuciones gubernativas, á no ser que se determine otra cosa por leyes especiales. Conforme á este principio, las disposiciones de este libro no excluyen ni limitan las atribuciones que por leyes de 8 de Enero, 2 de Abril de 1845, y cualquiera otras especiales competan á los agentes de la Administración para dictar bandos de policía y buen gobierno, y para corregir gubernativamente las faltas en los casos en que su represión les esté encomedada por las mismas leyes". 


\section{La posición de la doctrina}

Ante estas disposiciones, parte de nuestra doctrina penal ha seguido el pensamiento clásico en esta materia defendido por la tesis sustancialista ${ }^{28}$, pero también se han planteado otras dos interpretaciones posibles de las normas citadas centrada en la identidad o no de las penas y las sanciones administrativas, aunque al final estas llegan a idénticos resultados o propuestas sobre la cuestión. Por una parte, se ha seguido estrictamente la letra de la ley y se ha afirmado que las sanciones administrativas no son penas. Así lo señala Eduardo Novoa, quien comentando el artículo 20 expresa que "la decisión de la controversia (como muchos de los penalistas mencionados también lo entienden), ha de buscarse en los textos legales positivos de cada país. [...] porque el legislador chileno, que en esto no hace sino reiterar un fenómeno universal, no dicta sus leyes ajustándose a un determinado sistema doctrinario". De esta forma sostiene que en nuestro ordenamiento existen varios argumentos para afirmar que el Derecho penal chileno es distinto al Derecho penal administrativo vigente entre nosotros ${ }^{29}$. No obstante lo anterior, aboga porque el legislador se preocupe de rodear la aplicación del Derecho penal administrativo de garantías semejantes a las que están incorporadas al Derecho penal, como forma adecuada para mantener el respeto por la dignidad y los derechos del hombre ${ }^{30}$. Por otra parte, Enrique Cury da sólidos argumentos positivos para sostener que las sanciones administrativas son penas, ya que si bien nuestro legislador nos la repute como tales, de forma implícita les reconoce dicha naturaleza: "el empleo del verbo reputar en el encabezamiento de la norma subraya el carácter artificioso de la distinción, pues significa que no se las tendrá por penas no obstante que naturalmente lo son" 31 . Más adelante trata de establecer cuáles habrían sido las razones que llevaron al legislador a hacer esta distinción: evitar el carácter deshonroso y aflictivo que rodean a la pena penal; sustraerlas del principio de legalidad y de su aplicación judicial, para hacer más expedita su imposición, considerando su escasa significación; evitar que los Tribunales se vieran abrumados por una multitud de asuntos sin importancia; y permitir que ciertas penas se administraran de forma más discrecional ${ }^{32}$. Ahora bien, considerando que las sanciones administrativas constituyen una necesidad impuesta por la complejidad de la sociedad contemporánea, también Cury termina formulando algunas propuestas de lege ferenda en su regulación: deben comprender infracciones leves; no se puede sancionar un mismo hecho con una sanción gubernativa y una pena criminal; se debe aplicar el principio de culpabilidad; se deben respetar las garantías de un procedimiento racional y justo, que incluye la presunción de inocencia; estas sanciones deben ser objeto de revisión judicial; y tender hacia una tipificación más precisa de las mismas ${ }^{33}$. Por último, tal como lo

\footnotetext{
${ }^{28}$ Cfr. Cousiño, Luis. Derecho penal chileno. T. I, Editorial Jurídica de Chile, Santiago, 1975, pp. 23-26.

${ }^{29}$ Novoa, E. Curso de Derecho penal chileno. $3^{\text {a }}$ ed., Editorial Jurídica de Chile, Santiago, 2010, p. 39.

${ }^{30}$ Ídem, p. 40.

${ }^{31}$ Cury (nota 1), p. 107.

32 Ídem, p. 108.

33 Ídem, pp. 109-112.
} 
hemos señalado anteriormente, para Cury el elemento determinante de la distinción entre pena y sanción administrativa -partiendo de su identidad ontológica-, es el quantum o la gravedad ético-social que se asigna a la conducta, lo cual trasunta necesariamente en el castigo que se va a aplicar.

En definitiva, ya sea que exista una identidad ontológica o no entre las penas y las sanciones administrativas, la conclusión a la que arriban nuestros autores es que deben implementarse mecanismos para dotar de mayores garantías a los particulares frente al ejercicio del poder punitivo entregado a la Administración del Estado, pues desde el punto de vista del derecho positivo, la sanciones administrativas no están sometidas al régimen de las penas. Sin embargo, esto no resuelve el tema de fondo sobre la existencia de una identidad ontológica entre ambos ilícitos y, en su caso, la posibilidad de que el legislador pueda tener límites cualitativos en su configuración.

Por su parte, en un trabajo notable y visionario, Luis Rodríguez Collao analiza el problema desde una perspectiva constitucional, con el objeto de llegar a un identidad ontológica entre pena y sanción administrativa, a fin de establecer un estatuto común para ambas a nivel de la Carta Fundamental ${ }^{34}$. En este sentido, sostiene la existencia de un concepto amplio y restringido de pena. El concepto amplio comprende todas las sanciones que aplican los órganos del Estado, mientras que el concepto restringido comprende solo aquellas contenidas en el Código Penal, según su artículo 20. En este punto coincide con Enrique Cury con relación a la naturaleza de las sanciones administrativas, pero llega a una solución jurídica que no solo se queda en el plano de la política legislativa, pues entiende que el concepto de pena que sigue nuestra Carta fundamental en su artículo 19 tiene un sentido amplio, esto es, abarca a las penas penales y a las penas administrativas, con las garantías que le son propias (legalidad, tipicidad, irretroactividad, culpabilidad). Con esta tesis, Rodríguez Collao adelanta la posición que tendrá la jurisprudencia a mediados de la década siguiente. Además, resuelve un problema capital, como es el de las garantías mínimas que se deben respetar en el ejercicio de la potestad punitiva de la Administración. Sin embargo, también se debe reconocer que no resuelve otra tema que es central, me refiero a los límites que tiene el legislador al momento de modelar la potestad punitiva de la Administración frente a la regulación y tipificación de la potestad punitiva penal.

\section{La jurisprudencia nacional}

Con relación a la jurisprudencia nos encontramos con los pronunciamientos del Tribunal Constitucional, la Corte Suprema y la Contraloría General de la República. En general, la posición que han seguido en esta materia ha sido la de plegarse a la doctrina y jurisprudencia española centrada en el ius puniendi único del Estado (identidad ontológica) que se proyecta en el ámbito penal, mediante el delito y la pena, y en el ámbito administrativo por medio de las infracciones y sanciones administrativas.

\footnotetext{
${ }^{34}$ Rodríguez (nota 2), pp. 117-163.
} 
En este sentido, el Tribunal Constitucional ha sostenido que "las sanciones administrativas participan de las características esenciales de las sanciones penales al ser ambas emanaciones del ius puniendi estatal, por lo que debe aplicarse, con matices, similar estatuto"35, llamándolas derechamente "penas" 36 . Esta también ha sido la línea seguida por la Contraloría General de la República ${ }^{37}$ y la Corte Suprema ${ }^{38}$.

En definitiva, para estos órganos no hay delitos ni infracciones por naturaleza, pues estos son establecidos y configurados como tales por el legislador. Además, en esta labor es el propio legislador el que valora estas conductas considerando su gravedad, entrega su conocimiento y aplicación a los jueces o a la Administración. Es, en definitiva, una cuestión de política legislativa sujeta, empero, al marco constitucional.

\section{El Derecho administrativo SANCiOnAdor COMO DISCIPLINA AUTÓNOMA AL DERECHO PENAL}

El análisis dogmático de las sanciones administrativas ha decantando a comienzos de la década de los 90 en la formulación de una concepción que pretende dar al Derecho administrativo sancionador una sustantividad como respuesta a la teoría del ius puniendi único del Estado, que -como hemos visto- ha sido recogida con particular entusiasmo por nuestra jurisprudencia y doctrina ${ }^{39}$. No se trata de un retorno a las tesis clásicas

${ }^{35}$ Sentencia Rol No 1518-09, de 21 de octubre de 2010, considerando $6^{\circ}$.

36 Ídem, considerando $7^{\circ}$.

${ }^{37}$ El ente contralor ha señalado que "[...] el origen histórico de las sanciones administrativas como un simple desplazamiento de la competencia desde el ámbito de los tribunales hacia el de la Administración, justificado por razones de conveniencia y de política legislativa [...] la distinción de estos dos ámbitos sancionatorios obedece exclusivamente a un criterio cuantitativo, puesto que el ilícito administrativo, comparado con el de naturaleza penal, es un injusto de significación ético-social reducida, que por razones de conveniencia y de política legislativa se ha encargado a la Administración” (Dictamen N 28.226, de 2007).

38 Al respecto, la Corte Suprema ha señalado "[... si bien principios elementales entre una y otra son comunes y lógicos, como ocurre con los relativos al non bis in Ídem, a la irretroactividad de la ley sancionadora, al principio pro reo y a la necesidad de prescripción de la respectiva acción persecutoria, no es posible desentenderse de la imposibilidad jurídica que se advierte en asimilar la contravención administrativa a una falta penal -única manera de concluir en un plazo de prescripción de seis meses para la respectiva acción persecutoria- la que surge de la naturaleza intrínseca del castigo [...] Desde luego, por cuanto la sanción penal presenta características ineludibles, suficientemente estudiadas por la doctrina, como son las de su moralidad, esto es, su fundamento ético; su aflictividad, destinada al restablecimiento del equilibrio social perturbado; su proporcionalidad a la naturaleza de la ilicitud penal de que se trate; su personalidad o individualidad; su igualdad, esto es, una misma conducta debe tener una idéntica sanción; su ejemplaridad, es decir, su potencialidad de intimidación; su publicidad, no solo respecto del castigo sino del justo proceso que a ella condujo; su certeza e ineludibilidad; su prontitud, con relación a su comisión; su revocabilidad para remediar una eventual injusticia; su temporalidad y divisibilidad, para amoldarse a las características del hechor, todas condiciones no necesariamente presentes en la sanción administrativa, pero sí, aplicables a crímenes, simples delitos y faltas [...]". Cfr. Sentencia de la Corte Suprema de10 de septiembre de 2009, causa Rol No 3357-09, considerandos $8^{\circ}$ y $9^{\circ}$.

${ }^{39}$ Véase, entre otros, Vergara, A. "Esquema de los principios del Derecho administrativo sancionador", en Revista de Derecho, Universidad Católica del Norte, año 11, No 2, 2004, pp. 137-147. 
formuladas dentro del Derecho penal de policía y del Derecho penal administrativo, desarrolladas en la segunda mitad del siglo XIX y primera mitad del siglo XX. En este caso, nos encontramos ante una propuesta dogmática que le reconoce sustantividad al Derecho sancionador administrativo, en cuanto Derecho administrativo y no como parte de los principios del orden penal. Su precursor ha sido el destacado catedrático Alejandro Nieto, cuya línea de pensamiento ha sido seguida por parte importante de la doctrina española ${ }^{40}$.

El presupuesto básico de esta tesis parte de una crítica severa a la teoría del ius puniendi único del Estado, que entiende que los delitos/penas y las infracciones/sanciones administrativas forman parte de un tronco común y, por tanto, sujeto a principios que también son comunes. En primer lugar, se atribuye a esta teoría una enorme deficiencia en su construcción que da lugar a una fragilidad dogmática evidente. Hay varias razones para ello: el ius puniendi no solo está radicado en el Estado, sino en otras entidades u organismos, como entidades supranacionales, territoriales e, incluso, no administrativas. A lo anterior se agrega la falta de un fundamento positivo en su formulación, particularmente en la Constitución española de 1978. A su vez, la letra del artículo 25 del texto constitucional no da la suficiente cobertura para sostener dicha tesis.

Resulta evidente que la concepción unitaria del poder punitivo estatal se construye de una categoría metajurídica que lleva a una identidad ontológica entre los delitos y las infracciones administrativas. Hecho lo anterior, se proyecta su sometimiento a un régimen jurídico común. Sin embargo "a partir de este momento, en efecto, todo son contradicciones y despropósitos, demostrándose una vez más que los creadores de dogmas, con frecuencia, o no se dan cuenta de sus consecuencias jurídicas o, pura y simplemente, no se los toman en serio, limitándose a disfrutar intelectualmente del nuevo verbalismo que se inventan" 41 .

En opinión de Nieto, la identidad ontológica debe ser analizada desde una perspectiva normativa. Bien señala este autor que la identidad ontológica de dos figuras no garantiza necesariamente el mismo tratamiento jurídico: "nada impide al legislador tratar igual a dos seres diferentes por esencia (hombre y mujer) o tratar de modo igual a dos seres ontológicamente iguales (libres y esclavos, nacionales y extranjeros)”. Además, esta supuesta igualdad ontológica choca con un hecho fundamental: los ilícitos son de creación normativa. "El ilícito no existe en la realidad, es creado por la norma, de tal manera que sin norma no puede haber ilícito". En este sentido, es el legislador quien los crea y determina si su régimen jurídico será igual o diverso, tal como da cuenta el denominado proceso de despenalización ${ }^{42}$. Por su parte, llegados a este punto, nuestro autor sostiene de forma categórica que un estudio y análisis de esta materia debiera apoyarse en el Derecho público del Estado y olvidarse del Derecho penal. Por último,

${ }^{40}$ La propuesta dogmática de Alejandro Nieto aparece por primera vez en el año 1993 bajo el título de Derecho administrativo sancionador, Tecnos, Madrid, y al año 2005 ya iba en su $4^{\text {a }}$ edición.

${ }^{41}$ Cfr. Nieto, A. Derecho administrativo sancionador, $4^{\mathrm{a}}$ ed. Tecnos, Madrid, 2005, p. 160.

${ }^{42}$ Ídem, pp. 154-155. 
la tesis de la potestad punitiva única del Estado aparece como inútil, en la medida que no resuelve el problema central: cuál es el Derecho aplicable.

Es así como Nieto comienza a desarrollar los principios y notas que le darían esta particular autonomía al Derecho administrativo sancionador, como ocurre con el principio de legalidad y la tipicidad, centrado en la formulación de los tipos infraccionales, o el principio de culpabilidad, que considera el gran número de ilícitos administrativos frente al breve repertorio de ilícitos penales, lo que es determinante en las posibilidades de conocimiento de las mismas. Sin embargo, bien se ha demostrado que la propuesta de Nieto no es del todo congruente con los objetivos que se plantea, pues en definitiva no es posible soslayar la existencia de una estrecha cercanía con los problemas que se presentan en el Derecho penal, al punto que los estudios dogmáticos elaborados en el seno de la doctrina y jurisprudencia penal permiten explicar muchos aspectos oscuros respecto del régimen de las sanciones administrativas ${ }^{43}$.

Esta línea de pensamiento ha sido compartida por algunos autores nacionales, que han insistido en la idea de que el Derecho administrativo sancionador es autónomo y, por tanto, no forma parte del Derecho penal ${ }^{44}$. Sin embargo, esta tesis no resuelve un aspecto que es fundamental: reconociendo que existe un Derecho penal y un Derecho administrativo sancionador, ambos de proyección del Derecho público del Estado, no aparece resuelto el problema respecto de los límites a que debe someterse el legislador en su configuración, más aún si se reconoce que en el ámbito de la Administración las garantías se hacen más flexibles o tenues. Además, siendo ambos instrumentos que están en poder del legislador, no resulta fácil comprender a ambos poderes punitivos como estancos separados, sin un lazo o vínculo alguno. Por lo demás, visto desde la perspectiva del derecho positivo, esta separación tan tajante no existe, como se aprecia en materia tributaria o aduanera.

\section{LA REVISIÓN DE LOS FUNDAMENTOS DE LA POTESTAD SANCIONADORA DE LA ADMINISTRACIÓN EN EL MARCO DE UN POLÍTICA REPRESIVA ESTATAL}

\section{Consideraciones generales: El Derecho penal colateral (Nebenstraftsrecht)}

Una vez hecho el análisis de las distintas posiciones que intentan explicar la relación entre los delitos y las infracciones administrativas, se llega a una suerte de callejón sin salida que enfrenta las posiciones dogmáticas y la Constitución. Por una parte, las tesis de la separación sustancial entre unas y otras demuestran evidentes falencias cuando nos

43 Véase, López López, H. El principio de culpabilidad en materia de infracciones tributarias, Thomson Reuters, Madrid, 2009, pp. 36-45.

${ }^{44}$ Román Cordero, C. "Derecho administrativo sancionador: ¿Ser o no ser? He ahí el dilema”, en Pantoja, R. (coord.), Derecho Administrativo. 120 años de Cátedra, Editorial Jurídica de Chile, Santiago, 2008, pp. 107-141. 
encontramos con tipos penales que en su estructura y fin no guardan mayores diferencias con las infracciones administrativas, especialmente aquellas que se construyen en el ámbito del medio ambiente, la salubridad pública o en materia urbanística, bajo formas de peligro abstracto. A su vez, las tesis formalistas tampoco resuelven de forma definitiva el problema, porque una explicación centrada únicamente en la autoridad que debe aplicar la sanción o en la cuantía o gravedad de la misma, no deja de plantear serios reparos, especialmente respecto de los límites que tendría el legislador en esta materia. Además, esta posición trata de mostrarse de forma aséptica frente a las concepciones valorativas o ético-social, pero implícitamente se plantean criterios cualitativos, como la imposibilidad de aplicar penas privativas de libertad por la vía administrativa o que las multas administrativas no sean convertibles en este tipo de sanciones, dejando siempre la sensación de que nos encontramos ante planteamientos de política legislativa y no de naturaleza dogmática.

Tal como lo plantea la doctrina moderna, el problema debe ser analizado desde la perspectiva del Derecho del Estado, considerando las funciones y deberes que el ordenamiento jurídico le ha impuesto, así como los instrumentos necesarios para cumplir dicha función. La posición que tiene el Estado frente al ser humano (servicialidad), el deber de promoción del bien común y de integración armónica de todos los sectores de la Nación que le impone la Carta fundamental (artículo $1^{\circ}$ ), exigen que este deba adoptar todas las medidas y ejercer las atribuciones que el ordenamiento jurídico le confiere destinadas a cumplir un rol de conformación social que responda a estos valores y bienes constitucionales. Estas exigencias han llegado a un crecimiento exponencial frente a una sociedad que se ha hecho más compleja desde la revolución industrial llegando a lo que se ha denominado la moderna sociedad del riesgo. Todo lo anterior ha demandado una intervención decidida del Estado mediante una acción oportuna y eficaz, la que muchas veces no se encuentra en la naturaleza, dinámica y ritualidad propia de los procesos judiciales y que exige, por lo tanto, asumir tal función por medio de sus órganos administrativos, dejando para una segunda fase el control jurisdiccional. Esto coloca a la actividad judicial en una función subsidiaria, especialmente en lo que se refiere al Derecho penal, respondiendo a la idea de que la represión criminal tiene el carácter de ultima ratio frente a las otras medidas que puede adoptar el Estado para satisfacer y proteger determinados valores y bienes constitucionales.

Sin embargo, una mayor sensibilidad y valoración de determinados bienes vitales que miran la sociedad en su globalidad, han hecho que conductas que provocan una amenaza cierta o posible atentado a las mismas, exijan no solo una represión por la vía administrativa, sino también por la vía penal. Es lo que se ha denominado como el Derecho penal en expansión, que tiende a abandonar los principios clásicos del Derecho penal y que asume la tipificación de nuevas conductas que puedan significar un atentado a bienes jurídicos que miran a la sociedad en su conjunto, como el medio ambiente, el urbanismo, la salubridad pública, el mercado, etc. ${ }^{45}$ Por lo tanto, frente al Derecho penal

${ }^{45}$ Sobre esta materia, se puede ver el interesante trabajo de Silva Sánchez, J. La expansión del Derecho penal. Aspectos de la política criminal en las sociedades postindustriales, Civitas, Madrid, 2001, 167 p., especialmente pp. 121 y ss. 
nuclear (Kernstraftsrecht) nos encontramos con un Derecho penal colateral (Nebestraftsrecht), también denominado Derecho penal de segunda velocidad, el cual se caracteriza porque en su mayoría castiga conductas que representan un mero peligro abstracto de bienes supraindividuales, es decir, el tema de la lesividad cede su importancia frente a normas o reglas que establecen estándares de funcionamiento en los sistemas sociales que deben ser respetados. Además, lo determinante en estas conductas es la visión global, sistémica o estructural, es decir, interesan las grandes cifras o analizar los comportamientos desde una perspectiva macro (macrosocial, macroeconómica, etc.). Por lo tanto, la conducta individual no tiene la capacidad de afectar esas grandes cifras, pero sí lo tendrá la acumulación de ellas. Esto es lo que ocurre en materia tributaria y aduanera, en donde una evasión no pone realmente en peligro la Hacienda Pública, sino que es el efecto sumativo de dicha conducta la que puede ser lesiva para este bien jurídico. Por último, la estructura de estos ilícitos se caracteriza por su referencia a normas extrapenales (urbanísticas, ambientales, tributarias, aduaneras, etc.) y por la posibilidad de sancionar a las personas jurídicas, que son los principales agentes que actúan en este ámbito ${ }^{46}$.

Según lo expuesto, resulta evidente la estrecha cercanía que tienen las infracciones administrativas con el Derecho penal colateral, a un punto tal que sería posible predicar la existencia de una identidad de fundamento y de fin entre ambas categorías de ilícitos. Más aún, siendo así, es posible separar la existencia de un Derecho penal nuclear, compuesto por ilícitos que lesionan bienes jurídicos individuales o los colocan en una situación de peligro concreto frente a un Derecho penal colateral, en donde el legislador puede comprender ilícitos penales e ilícitos administrativos, que se caracterizan por configurar conductas de peligro abstracto de bienes jurídicos supraindividuales.

Esta distinción permite comprender cómo juega la potestad punitiva del Estado en la configuración de los ilícitos, en la medida que el legislador castiga las conductas consideradas en el Derecho penal nuclear solo por la vía penal, mientras que en el caso del Derecho penal colateral, sigue criterios de eficacia u oportunidad para determinar qué conductas serán sancionadas por la vía judicial (delitos) o administrativa (infracciones). Los delitos contra la vida, la integridad física y el patrimonio constituyen parte de este espacio del Derecho penal nuclear, y aparece como algo inimaginable que estos puedan ser entregados al conocimiento y aplicación por parte de órganos administrativos. Por su parte, aquellos ilícitos que tienen por objeto la protección del medio ambiente, la libre competencia, el urbanismo, el mercado financiero, etc., bien pueden ser sancionados por la vía penal o por la vía administrativa, cuestión que no plantea mayores objeciones en el marco de una política pública que tiende a lograr determinadas metas y objetivos, en donde la potestad punitiva del Estado aparece como uno de los instrumentos que necesariamente se orienta a dicha finalidad. En esta determinación será el legislador quien tendrá que ponderar la forma de actuar, sujeto a la ritualidad y formas propios del proceso judicial o mediante las técnicas y mecanismos de actuación que son inherentes a los órganos que forman parte de la Administración del Estado. En uno y otro camino

\footnotetext{
${ }^{46}$ Una acabado análisis de este tema se puede ver en López (nota 43).
} 
se tendrá que tener presente la relación directamente proporcional que se produce entre la gravedad de la sanción que se pretende aplicar y las garantías que amparan la posición del particular.

Tal como se ha expuesto, parece del todo lógico y razonable la forma como se conforma el abanico de opciones que tiene el legislador al momento de regular los ilícitos penales y administrativos. Sin embargo, todavía queda por resolver si esta forma de actuación resulta admisible a la luz de nuestro ordenamiento constitucional, que es en definitiva lo determinante en esta materia.

\section{El problema desde el punto de vista constitucional}

La constitucionalidad de la sanción administrativa es un tema que no ha despertado en nuestra doctrina y jurisprudencia un gran debate, a pesar que se han planteado serios cuestionamientos por parte de la doctrina, con argumentos que pueden parecer simples, pero que resultan difíciles de rebatir ${ }^{47}$. Por su parte, nuestro Tribunal Constitucional no se ha hecho cargo del tema y solo ha dado por supuesto su legitimidad constitucional ${ }^{48}$.

El escollo más importante lo constituye el tema de la naturaleza jurídica de las sanciones administrativas y los elementos que permiten distinguirla de las sanciones penales. En este sentido, Eduardo Soto Kloss ha sostenido que la potestad sancionadora de la Administración constituye el ejercicio de una función jurisdiccional, que es de competencia exclusiva de los tribunales de justicia. Por lo tanto, su atribución y ejercicio por autoridades gubernamentales y administrativas constituye una clara vulneración de lo previsto en la Carta fundamental (artículos $19 \mathrm{~N}^{\circ} 3$ inc. 4 y 76) ${ }^{49}$.

${ }^{47}$ Véase Soto Kloss, E. "Derecho Administrativo Penal. Notas para el estudio de la potestad sancionadora de la Administración”, en Boletín de Investigaciones, Facultad de Derecho de la Pontificia Universidad Católica de Chile, N $\mathrm{N}^{\circ}$ 44-45, 1979/1980, pp. 95-103, y, del mismo autor, "La potestad sancionadora de la Administración, ¿se adecua a la Constitución?”, en AA.VV. Sanciones Administrativas y Derechos fundamentales: regulación y nuevo intervencionismo. Universidad Santo Tomás, Santiago, 2005, pp. 29-49. En el mismo sentido, Aróstica, I. "Algunos problemas del Derecho Administrativo Penal”, en Revista de Derecho, Universidad de Concepción, $\mathrm{N}^{\circ} 182,1987$, pp. 71-81.

48 Véase Sentencia del Tribunal Constitucional Rol N $\mathrm{N}^{\circ}$ 792, de 3 de enero de 2008, en particular su considerando $16^{\circ}$ en donde señala que "[...] si bien puede resultar lícito que los órganos fiscalizadores puedan, previo al proceso judicial y en el ámbito administrativo, determinar la existencia de una infracción y la cuantía de una multa, la sanción no puede estimarse como cierta e irrevocable para el ordenamiento jurídico sino una vez que no haya sido reclamada o que, habiéndolo sido, tal reclamo haya sido resuelto en sede jurisdiccional e independiente. Así lo consagra nuestro sistema al permitir que se recurra de las respectivas decisiones administrativas ante los tribunales, cuestión que no solo está consagrada a nivel legal, sino que también, con mayor jerarquía, en la propia Constitución Política (artículo 38, inciso segundo)".

${ }^{49}$ En este sentido, sostiene que "[...] si sancionar es juzgar, y si para juzgar se requiere estar habilitado jurídicamente por la Constitución y el ordenamiento constitucional, y ello en Chile se ha entregado a los tribunales de justicia, y más encima ello debe hacerse mediante el debido procedimiento (racional y justo), no parece sino elemental el preguntarse ¿cómo, entonces, el administrador -sea el Presidente de la República, un jefe de servicio, un intendente, etc.- puede imponer sanciones administrativas sean multas, sean comisos, sean clausuras de locales, sean retiros de actos autorizatorios, sean conductas determinadas, etc., si carece constitucionalmente de jurisdicción? Si el Presidente de la República carece de toda potestad 
Por su parte, en la misma línea se pronunciaba en siglo XIX don Jorge Hunneus a propósito de las facultades sancionadoras otorgadas a los Gobernadores bajo el imperio de la Constitución de $1833^{50}$.

Ante dichos cuestionamientos, otros autores han tratado de dar argumentos en contrario, todos los cuales también están sujetos a críticas y reparos que no son menores ${ }^{51}$, o se apoyan en razones que se fundan en la conveniencia o necesidad de dicho poder en manos de la Administración, sin que se encuentre un fundamento positivo sólido ${ }^{52}$.

A nuestro parecer el centro de la cuestión se encuentra en la identificación que se hace a nivel constitucional entre delito, pena y autoridad judicial. Esta es la interpretación tradicional que se realiza del artículo 76 de la Constitución, cuando se entrega de forma exclusiva a los tribunales el conocimiento de las "causas civiles y criminales". Por lo tanto, la relación es la siguiente: el legislador establece las conductas constitutivas de delito y la pena correlativa, mientras que corresponde al juez determinar en un proceso judicial la comisión de una conducta delictiva y, en caso de que esta se hubiese verificado, establecer para el caso en concreto la pena que corresponde aplicar. Según esta premisa, la conclusión parece ser simple y lapidaria: todo castigo o sanción que dispense el Estado como consecuencia de una conducta ilícita, solo puede ser aplicada por la vía judicial.

jurisdiccional, y para ordenar detenciones la Constitución ha debido regular expresamente tal posibilidad, y para el caso del estado de sitio ¿cómo es que la Administración que le está subordinada puede imponer sanciones? Porque es una realidad que día a día la Administración impone castigos, no solo a sus agentes (funcionarios), sino a los simples ciudadanos, a los usuarios de servicios públicos, a quienes contratan con ella, a quienes son beneficiarios de una autorización, de una subvención, de un acto de admisión, en fin, de cualquier acto administrativo de beneficio”. Cfr. Soto Kloss (nota 47), p. 95.

${ }^{50}$ Hunneus, J. La Constitución ante el Congreso. T. II, $2^{\mathrm{a}}$ ed., Imprenta Cervantes, Santiago, 1891, pp. 229-231.

${ }^{51}$ En este sentido, Luis Rodríguez Collao señala tres argumentos: a) el reconocimiento y persistencia histórica de la potestad punitiva de la Administración; b) la interpretación del artículo 73 de la Constitución (actual artículo 76), que permitiría atribuir facultades jurisdiccionales a órganos administrativos en calidad de tribunales especiales; c) que los cuestionamientos solo van dirigidos a las sanciones gubernativas y no comprenden las sanciones disciplinarias, que también son de naturaleza administrativa; y d) No existe ninguna norma constitucional que prohíba a la Administración ejercer una potestad sancionadora. A este respecto, bien se ha señalado que la tradición o persistencia de una institución en el tiempo no constituye título suficiente para sostener su constitucionalidad. Por otra parte, es una cuestión asentada en la legislación, la jurisprudencia y la doctrina, que no resulta admisible atribuir facultades jurisdiccionales a órganos administrativos, en la medida que no se garantice la suficiente independencia e imparcialidad en su actuar. Además, el hecho de que no se rebata la constitucionalidad de la potestad disciplinaria, no altera los serios cuestionamientos respecto de las sanciones gubernativas. Por último, en Derecho público el silencio del Constituyente implica necesariamente la prohibición de actuar y no a la inversa como se sostiene (artículo 7 inc. $2^{\circ}$ ). Véase, Rodríguez (nota 2), pp. 132-134.

52 Véase Román Cordero, C. "El castigo en el Derecho administrativo”, en Derecho y Humanidades, No 16, Vol. 1, 2010, pp. 155-171, pp. 158-159. También en Román Cordero (nota 44), pp. 107-141. También se puede ver Camacho Cepeda, G. "La legitimidad de la Potestad Administrativa Sancionadora", en Revista de Derecho Público, Vol. 69, N 2, 2007, pp. 9-23. Una relación de estas posturas se puede encontrar en Boettiger Philipps, C. "El derecho administrativo sancionador en la jurisprudencia del Tribunal Constitucional", en Revista Actualidad Jurídica, No 20, Julio, 2009, pp. 580-584. 
Sin embargo, creo que esta interpretación parte de una premisa errónea, que lleva también a una interpretación que no se corresponde con lo previsto en nuestras normas constitucionales. Analicemos este punto con detenimiento:

1) Tal como lo han sostenido algunos autores, el concepto constitucional de pena es más amplio que el contenido en la legislación penal, particularmente el Código penal ${ }^{53}$. Por lo demás, así se ha demostrado del estudio de las actas de la Comisión de la Nueva Constitución ${ }^{54}$. Para efectos constitucionales, especialmente en lo dispuesto por el artículo 19 de la Constitución, el concepto de pena comprende toda sanción aplicada por un órgano del Estado. Por su parte, debemos entender que la pena siempre tiene un carácter aflictivo o represivo como consecuencia de una actuación ilícita. Así las cosas, no solo constituyen penas las sanciones previstas para la comisión de delitos, sino también son penas las sanciones que aplica la Administración como consecuencia de una infracción administrativa. Como corolario de lo anterior, para nuestra Constitución existe una identidad ontológica entre sanción penal y sanción administrativa, ya que ambas tienen los mismos elementos sustanciales: son una reacción estatal represiva frente a un acto ilícito.

2) Como parte del mismo género, la pena penal y la pena administrativa se someten a un mismo estatuto constitucional, que consagra garantías mínimas tanto sustantivas como procedimentales: legalidad, tipicidad, culpabilidad, irretroactividad, justo y racional procedimiento previo. Este es, por lo demás, una de las conclusiones a las cuales llega el Tribunal Constitucional al sostener la tesis del ius puniendi único del Estado y la proyección de los principios del orden penal al ámbito de la sanciones administrativas, aunque con algunos matices ${ }^{55}$. Más aún, expresamente ha señalado que las sanciones administrativas participan de los elementos esenciales de las sanciones penales ${ }^{56}$.

Si bien resultaba del todo innecesario recurrir a la tesis española del ius puniendi único para sostener la aplicación de los principios comunes que la Constitución establece en el ámbito punitivo, sí era de la mayor relevancia destacar que no solo los antecedentes y la discusión habida al interior de la Comisión de Estudios de la Nueva Constitución sustenta la idea de un concepto amplio de pena, sino que es el propio Tribunal Constitucional el que en una jurisprudencia reiterada ha respaldado dicha interpretación.

3) La posibilidad de que una determinada conducta sea sancionada por la vía administrativa o judicial, es una cuestión de política legislativa, cuya determinación queda entregada, en principio, al juicio de mérito que al respecto realice el Legislador. Así lo ha entendido -aunque con algunos reparos- el propio Tribunal Constitucional ${ }^{57}$.

53 Cfr. Rodríguez (nota 2).

54 Aguerrea Mella, p. "El estatuto constitucional de las penas. Su aplicación a las sanciones administrativas según los antecedentes de la Comisión de Estudio de la Nueva Constitución”, en AA.VV. Sanciones Administrativas y Derechos fundamentales: regulación y nuevo intervencionismo. Universidad Santo Tomás, Santiago, 2005, pp. 51-62.

55 Cfr. Sentencias Rol N ${ }^{\text {os }} 244$, de 1996; 479 y 480, de 2006; 725 y 766, de 2008; 1.183, 1.184, $1.203,1.205,1.221$ y 1.229 , de 2009; y 1.518 , de 2010 .

${ }^{56}$ Cfr. Considerando 6 ${ }^{\circ}$, Sentencia Rol No 1.518 , de 2010.

${ }^{57}$ En este sentido, el Tribunal Constitucional ha señalado que "[...] no debe desconocerse la circunstancia de que, aunque se trata de una cuestión de mérito que debe resolver el legislador, se ha cuestionado la circunstancia 
4) No obstante lo anterior, el Constituyente ha establecido determinados límites generales y específicos a los cuales debe someterse el legislador al momento de tipificar una determinada conducta como ilícito administrativo o penal.

a. En primer término, el Legislador al momento de determinar la sanción debe aplicar el principio de proporcionalidad, considerando la intensidad de la limitación que se impone a un derecho fundamental y el objetivo constitucional válido que se busca perseguir: "una limitación a un derecho fundamental es justificable, cuando dicho mecanismo es el estrictamente necesario o conveniente para lograr un objetivo constitucionalmente válido, debiendo consecuentemente el legislador elegir aquellas limitaciones que impliquen gravar en menor forma los derechos fundamentales" 58 .

b. Las penas privativas de libertad solo se pueden imponer previa intervención de la autoridad judicial (artículos $19 \mathrm{~N}^{\mathrm{os}} 1$ y 7 Constitución). En este sentido, el Tribunal Constitucional ha señalado que una disposición "infringe lo dispuesto en el artículo 19 , números $1^{\circ}$ y $7^{\circ}$, de la Constitución, desde que se trata de un verdadero apremio ilegítimo, al importar una pena privativa de libertad impuesta por la vía administrativa y sin que previamente exista una instancia jurisdiccional que revise dicha actuación" 59 .

c. En tercer término, el Tribunal ha sostenido que tampoco es posible que una sanción administrativa de multa pueda ser convertida por vía sustitutiva en una pena privativa de libertad, a diferencia de lo que ocurre con las sanciones penales ${ }^{60}$. Nuevamente en este caso se coloca como elemento determinante la no intervención judicial en la medida que decreta la privación de libertad.

5) De acuerdo con lo anteriormente expuesto, desde la perspectiva constitucional no constituye una competencia exclusiva de los jueces aplicar una pena, ya que también esta puede ser entregada al conocimiento de la autoridad administrativa. Sin embargo, si el legislador determina que se encuentra ante conductas de la mayor gravedad, que deben ir necesariamente aparejadas de penas privativas de libertad -ya sea de forma directa o

que sea la propia administración la que conozca de materias sancionatorias”. Cfr. Considerando $28^{\circ}$, Sentencia Rol $\mathrm{N}^{\circ} 725$, de 2008.

${ }^{58} \mathrm{La}$ aplicación del principio de proporcionalidad aparece aplicado en general en las Sentencias Rol Nos. 226, considerando $47^{\circ} ; 280$, considerando $21^{\circ}$; y 519 , considerando $19^{\circ}$. En relación con las sanciones administrativas en particular, se puede ver la Sentencia Rol N ${ }^{\circ} 1.518$, considerando $14^{\circ}$.

${ }^{59}$ Cfr. Considerando $22^{\circ}$, Sentencia Rol N ${ }^{\circ} 1.518$.

${ }^{60}$ En este sentido ha señalado que "[...] en lo que se refiere al apremio que consagra el primer inciso del artículo impugnado, este no puede considerarse de aquellos amparados por el orden constitucional y, por consiguiente, legítimo, toda vez que consiste en una limitación a la libertad que en sí misma no tiene la finalidad propia de un apremio, esto es, compeler a un individuo a realizar una determinada conducta, sino más bien, como ya se señaló, es una pena privativa de libertad utilizada como forma de apremio o presión, por lo que en sí misma importa una reacción punitiva ante una conducta del individuo que viene a reemplazar por vía de sustitución el pago de una multa y que, por consiguiente, su finalidad es más bien sancionar al responsable de un acto. De esta manera, mal podría considerarse que se está en presencia de un apremio legítimo si este a su vez importa el castigo de una conducta que, como se apreciará, no es aún del todo reprochable, desde el momento que se ha impetrado a la jurisdicción ordinaria con el objeto de que esta determine si existe realmente una determinada responsabilidad imputable a los recurrentes". Cfr. Considerando $10^{\circ}$, Sentencia Rol No 1.518 . 
por vía de sustitución-, solo corresponde a los tribunales de justicia el conocimiento de estos asuntos y la facultad de aplicar dichas sanciones, según el mérito del proceso.

Dicho en otros términos: los actos ilícitos que conllevan como sanción penas privativas de libertad, son de competencia exclusiva de los tribunales de justicia. En caso contrario, corresponde al legislador determinar si las conductas serán sancionadas por la vía administrativa o por la vía penal.

Además, esta interpretación se corresponde con el alcance del artículo 76 de la Constitución, que entrega al conocimiento de los jueces no cualquier delito o ilícito penal, sino sólo los “crímenes", entendiendo que son aquellas conductas que merecen las más altas sanciones. En efecto, la expresión crimen da cuenta de la comisión de ilícitos de la mayor gravedad y reproche, que se traduce en penas proporcionales a las mismas.

6) Si examinamos estas conclusiones a la luz de la distinción entre Derecho penal nuclear y Derecho penal colateral, de inmediato se comprueba que en el ámbito del Derecho penal nuclear nos encontramos ante normas que responden al carácter subsidiario que se demandan de disposiciones de esta naturaleza, en donde las sanciones deben ser aplicadas por la vía judicial. Sin embargo, en el caso del Derecho penal colateral corresponde al legislador determinar la política represiva que se tendrá que seguir, ponderando la forma más eficaz y oportuna para proteger determinados bienes jurídicos supraindividuales. Si dichas conductas dan lugar a las máximas sanciones que se pueden aplicar en nuestro sistema, la intervención de la autoridad judicial es ineludible (Derecho penal), en caso contrario, bien puede canalizar el poder punitivo mediante órganos administrativos. Así, si un agente económico por negligencia no informa al mercado de un hecho esencial, su conducta podría ser sancionada por la vía administrativa, a diferencia de lo que ocurre con el agente que de forma deliberada y consciente no entrega dicha información, pues en tal caso deberá seguir la vía penal, salvo que el Legislador determine que dicha conducta puede ser sancionada por la vía administrativa mediante penas que no impliquen ni directa ni indirectamente una privación de libertad.

\section{Conclusiones}

El estudio de las infracciones administrativas y su relación con el Derecho penal, ha planteado siempre una discusión en torno a la naturaleza y elementos que permitirían distinguirlas de los delitos. Este tema se ha vuelto más relevante aún a partir de los principios y mandatos constitucionales, que reservan a la competencia de los tribunales de justicia el conocimiento y resolución de aquellas medidas represivas que puede adoptar el Estado frente a los particulares y que necesariamente implican una limitación y/o restricción de derechos fundamentales. El tema se hace aún más difícil de analizar frente a un crecimiento exponencial de las potestades punitivas de la Administración, que encuentra su fundamento en una realidad más compleja producto de cambios sociales cada vez más acelerados, pero que no deja de trastabillar ante los principios constitucionales y la forma en que debe ser comprendido el problema desde un punto de vista dogmático. 
El análisis de la cuestión desde las formulaciones iusnaturalistas en el período del Estado de policía hasta nuestros días, nos lleva a sostener que no existe una diferencia ontológica entre las sanciones penales y las sanciones administrativas. Ambos son instrumentos con los cuales cuenta el Estado en su función de conformación social en el marco de protección y resguardo de determinados valores y bienes constitucionales. En este caso, se debe entender que estamos frente a mecanismos represivos que nuestro ordenamiento pone a disposición del Estado para cumplir su función constitucional al servicio de la persona humana y de promoción del bien común. Sin embargo, para su ejercicio, el primer paso que debe dar el Estado es por medio de la ley. El principio de legalidad es un elemento común e ineludible en la determinación de los ilícitos y las penas. A su vez, el siguiente paso será determinar si el castigo o represión de dichas conductas se realizará por la autoridad judicial o por la autoridad administrativa. En esta segunda función, el legislador dispone de una facultad discrecional para seguir uno u otro camino, pues él debe ponderar su eficacia, mérito u oportunidad, aunque sujeto a una serie de limitaciones: el principio de proporcionalidad respecto de la sanción que se aplicará y que toda medida que implique privación de libertad, ya sea de forma directa o sustitutiva, requiere de la intervención de la autoridad judicial, tal como lo ha sostenido nuestro Tribunal Constitucional.

De esta forma, también se puede comprender el sentido y fundamento de las sanciones administrativas frente a la expansión que ha tenido el Derecho penal en las sociedades postindustriales. Ni el Derecho penal ni el Derecho administrativo sancionador son estancos separados, sino que son espacios de actuación coordinada en el marco de una política represiva que el Estado puede implementar para cumplir su función constitucional. Existe un espacio que es propio o inherente al Derecho penal, en donde la Administración no tiene cabida (Derecho penal nuclear o Kernstraftsrecht), pero también existe otro ámbito en donde la eficacia en el actuar del Estado no se asegura solo con la intervención de la Administración, sino que requiere también la participación del poder judicial mediante sanciones de la mayor gravedad (Derecho penal colateral o Nebenstraftsrecht). Es en este espacio donde juega la sanción administrativa y comienza su relación dialéctica con las sanciones penales.

En definitiva, no existen delitos por naturaleza ni infracciones administrativas que tengan un contenido u objeto que sea exclusivo e inherente a las mismas. Ambas son manifestaciones del poder que tiene el Estado para reprimir determinadas conductas (ius puniendi), sujeto a determinados límites constitucionales, en donde la proporcionalidad se transforma en un elemento esencial.

\section{BIBLIOGRAFÍA}

Aguerrea Mella, P., "El estatuto constitucional de las penas. Su aplicación a las sanciones administrativas conforme a los antecedentes de la Comisión de Estudio de la Nueva Constitución”, en AA.VV. Sanciones Administrativas y Derechos fundamentales: regulación y nuevo intervencionismo. Universidad Santo Tomás, Santiago, 2005, pp. 51-62. 
Aróstica, I., “Algunos problemas del Derecho Administrativo Penal”, en Revista de Derecho, Universidad de Concepción, $\mathrm{N}^{\circ} 182,1987$, pp. 71-81.

Boettiger Philipps, C., "El derecho administrativo sancionador en la jurisprudencia del Tribunal Constitucional", en Revista Actualidad Jurídica, No 20, julio, 2009, pp. 577-596.

Camacho Cepeda, G., "La legitimidad de la Potestad Administrativa Sancionadora", en Revista de Derecho Público, Vol. 69, No 2, 2007, pp. 9-23.

Casetta, E., Voz: "Sanzioni amministrative”, en Digesto pubblico, XII, Torino, 1997.

Cerezo Mir, J., "Límites entre el Derecho penal y el Derecho administrativo", en Anuario de Derecho penal y Ciencias penales, Tomo XXVIII, Fascículo II, mayo-agosto, 1975, pp. 159-173.

Cousiño, L., Derecho penal chileno. T. I, Editorial Jurídica de Chile, Santiago, 1975.

Cury, E., Derecho Penal. Parte General, 8ª ed., Universidad Católica de Chile, Santiago, 2005.

Feuerbach, P. J. A., Anselm Ritter von Feuerbach's Leben und Wirken: aus seinen ungedruckten Briefen und Tagëbüchern, Vorträgen und Denkschriften, publicado por su hijo Ludwig Feurbach, Leipzig, 1852 (edición facsimilar publicada en Estados Unidos por Nabu Press, 2012).

Gioia, V. y Scavonetto, L., Le sanzioni amministrativa, Giappichelli, Torino, 2009.

Girola, C., "Sanzioni penali e sanzioni amministrative", en Rivista di Diritto Pubblico, I, 1929, pp. 429 y ss.

Hunneus, J., La Constitución ante el Congreso. T. II, $2^{\mathrm{a}}$ ed., Imprenta Cervantes, Santiago, 1891.

Jakobs, G. Derecho penal. Parte general. 2 ed. Marcial Ponst, Madrid.

LóPEZ LóPEZ, H. El principio de culpabilidad en materia de infracciones tributarias, Thomson Reuters, Madrid, 2009.

Mattes, H., Problemas de Derecho Penal Administrativo, Revista de Derecho Privado, Madrid, 1979.

Merkl, A., Teoría General del Derecho Administrativo, Comares, Granada, 2004.

Nieto, A., Derecho administrativo sancionador, 4 ed. Tecnos, Madrid, 2005.

Novoa, E., Curso de Derecho penal chileno. $3^{a}$ ed., Editorial Jurídica de Chile, Santiago, 2010.

Ranellettr, O., "La polizia di sicurezza", en Primo trattato completo di diritto amministrativo italiano, Orlando V. E. (dir.), IV, Milano: Società Editrice Libraria, 1904, pp. 207-1265.

Rodríguez, L., "Bases para distinguir entre infracciones criminales y administrativas", Revista de Derecho, Pontificia Universidad Católica de Valparaíso, Vol. XI, 1987.

Román Cordero, C., "Derecho administrativo sancionador: ¿Ser o no ser? He ahí el dilema", en Pantoja, R. (coord.), Derecho Administrativo. 120 años de Cátedra, Editorial Jurídica de Chile, Santiago, 2008, pp. 107-141.

Román Cordero, C., "El castigo en el Derecho administrativo", en Derecho y Humanidades, $\mathrm{N}^{\circ}$ 16, Vol. 1, 2010, pp. 155-171.

Roxin, C., Derecho penal. Parte general, T. I, Civitas, Madrid, 1997, p. 72.

SAndulli, A. M., Manuale di diritto Amministrativo, Giuffré, Milano, 1993.

Santamaría Pastor, J. A., Fundamentos de Derecho Administrativo, Centro de Estudios Ramón Areces, Madrid, 1991

Santamaría Pastor, J. A., Principios de Derecho Administrativo, II, 2 ed., Iustel, Madrid, 2009.

SCHMIDT, E., Lebrkommentar zur Strafprozessordnung und zum Gerichsverfassunsgesetz. Teil 1, 2a ed., Vandenhoeck \& Ruprecht, Göttingen, 1964.

Silva Sánchez, J., La expansión del Derecho penal. Aspectos de la política criminal en las sociedades postindustriales, Civitas, Madrid, 2001.

Soтo KLoss E., "La potestad sancionadora de la Administración, ¿se adecua a la Constitución?", en AA.VV. Sanciones Administrativas y Derechos fundamentales: regulación y nuevo intervencionismo. Universidad Santo Tomás, Santiago, 2005, pp. 29-49.

Soto Kloss, E., "Derecho Administrativo Penal. Notas para el estudio de la potestad sancionadora de la Administración", en Boletín de Investigaciones, Facultad de Derecho de la Pontificia Universidad Católica de Chile, No 44-45, 1979/1980, pp. 95-103. 
Soтo Kloss, E., "La Fiskustheorie, una vinculación privatista del príncipe", en Derecho Administrativo. Bases Fundamentales, T. I, Editorial Jurídica de Chile, Santiago, 1996, pp. 175-220.

Vergara, A., "Esquema de los principios del Derecho administrativo sancionador", en Revista de Derecho, Universidad Católica del Norte, año 11, No 2, 2004, pp. 137-147.

Welzel, H., "Der Verbotsirrtum im Nebenstrafrecht", en Juristenzeitung, 1956, pp. 238-240. Zanobini, G., Le sanzioni amministrative. Bocca, Roma, 1924. 
